\title{
A Review on Organism Regrowth in UV-based Ballast Water Treatment Systems for the Approval of New G8 Guidelines
}

\author{
Jiaxin Chen ${ }^{1, a}$, Meina xie ${ }^{1, b}$, Sen Liang ${ }^{1, c}$, Ying Yang1, d, Wenting Guan ${ }^{1, e}$, \\ Cong Zhang ${ }^{1, f}$, Yong Liang ${ }^{1, g}$, Tianqi Li ${ }^{1, h}$, Lixuan Xu' ${ }^{1, i}$, Manxia Zhang ${ }^{1, j, *}$ \\ ${ }^{1}$ College of Environmental Science and Technology, Dalian Maritime University, Dalian 116026, \\ China \\ a918055461@qq.com, b799398626@qq.com, c18503532185@163.com, \\ dyangying1007zyx@163.com, eguanwenting28@163.com, 5584003203@qq.com, \\ 91808465979@qq.com, hltq15590896868@163.com, '18342212683@163.com, \\ jzhangmanxia@163.com
}

\begin{abstract}
Keywords: Ballast water management, UV-based, organism regrowth, new G8 guidelines
\end{abstract} Abstract. In light of urgent need of approval of ballast water management system against the new G8 guidelines, organism regrowth within treated ballast water should be assessed. However, it's the first time for mandatory demands on the evaluation of organism regrowth in ballast water. For the existances of DNA repair enzymes, UV-based systems have the risks of organisms regrowth after treatment. So far a range of algae and bacteria have been observed the recovery after UV irridation in the simulated ballast water or real ballast water during 1-day to 9-day culture. The target organisms, UV doses, recovery date and regrowth enviroment will be compared in such regrowth experiments. Also, the possible pathways of the regrowth will be discussed in the paper, with the consideration of both light repair and dark repair. Based on the reviews of current researches, the available methods will be explored to inhibit the organism regrowth in the UV-based ballast water treatment systems. For the compliance of the new G8 guidelines, UV-based systems are supposed to be assessed on organism regrowth, and the modificaiton methodologies were suggested for the currently approved UV-based systems to minimize the regrowth risks.

\section{Introduction}

There is more than 100 billion tons of ballast water to be transferred by ships each year [1], and about 7000 species are carried with them every day. It may cause the invasion of exotic species, which has been ranked as one of the four major threats to the world's oceans. Consequently, marine environment, ecosystem of discharge port, human health may be affectedly adversely [1], and the economic losses caused by ballast water are growing at the rate of about $\$ 10$ billion a year [2].

The International Maritime Organization (IMO) has formally accepted the International Convention for the Control and Management of Ships Ballast Water and Sediments (BWM convention) in 2004[3], which has taken into effects in 2017. Meanwhile, the Guidelines for Approval of Ballast Water Management Systems (G8) have been updated in 2016 (MEPC.279 (70)). Different from the old version of G8 guidelines, the mandatory demands on the evaluation of organism regrowth within treated ballast water were put forward in the new G8 specifications for the first time. It means that all the approved ballast water treatment systems in line with old G8 guidelines, should be re-approved according to the new G8 guidelines, and the evaluation of organism regrowth should be carried out.

Currently 65 types of ballast water treatment system have been approved on the basis of the old G8 guidelines (according to statistics on MEPC69 conference). While 51\% of the approval systems have adopted UV-based methods, $39 \%$ of them use electrolysis-based ways, and only $10 \%$ of the systems use other technologies, such as ozone and deoxygenation methods. In the shipboard application and laboratory tests, UV-based ballast water treatment systems have been detected the risks of organism regrowth, whereas no regrowth has been reported in the systems of electrochemical, ozone and deoxygenating treatments since in such systems organisms are supposed to be fully decomposed. 
At present, UV-based systems normally combine filtration and UV irradiation in the treatment system, such as Hyde Guardian ${ }^{\mathrm{TM}}$ in the United States, GloEn-Patrol ${ }^{\mathrm{TM}}$ in Korea, Chinese Sea Shield, AHEAD, Cyeco ${ }^{\mathrm{TM}}$, BSKY ${ }^{\mathrm{TM}}$, Seascape, BALWAT. Also, quite a few UV-based systems adopt the UVC-photocatalytic method, such as Sea Doctoral system. In these systems, the primary processing of filtration may remove most of organisms in the ballast water, and the UV unit mainly deals with microalgae of the size below $50 \mu \mathrm{m}$ and microorganisms $[4,5]$ in ballast water.

To assess the compliance with the new G8 guidelines, the regrowth risks in the UV-based ballast water treatment systems will be reviewed comprehensively, and the possible regrowth pathways and inhibition methods on regrowth will be discussed in the paper.

\section{Organism regrowth in the UV-based ballast water treatment systems}

Organism Regrowth after UV Irradiation. So far, only a few studies have been done on the organism regrowth within treated ballast water. Table 1 summarized the current researches on organism regrowth in the simulated ballast water or real ballast water. As shown in Table 1, almost all the observed algae, bacteria and total organisms collected in the ballast water presented regrowth after UV-based treatment. It seems that the regrowth environment has little influence on the organism recover. The only exceptions are for organisms on the 5-day observation after $\mathrm{UVC}^{-\mathrm{TiO}_{2}}$ treatment, and for Microcystis aeruginosa during 10-day observation after $200-350 \mathrm{~mJ} / \mathrm{cm}^{2}$ UVC irradiation.

Table 1 Organism Regrowth in the UV-based Ballast Water Treatment Systems

\begin{tabular}{|c|c|c|c|c|c|}
\hline & $\begin{array}{l}\text { Initial Density } \\
(/ \mathrm{mL})\end{array}$ & $\begin{array}{l}\text { UV Doses } \\
\left(\mathbf{m J} / \mathrm{cm}^{2}\right)\end{array}$ & Regrowth & $\begin{array}{l}\text { Recovery } \\
\text { Date (days) }\end{array}$ & $\begin{array}{l}\text { Regrowth } \\
\text { Environment }\end{array}$ \\
\hline Chlorella autotrophica & $10^{5}-10^{6}$ & $100-400$ & Yes & 5 & \multirow{3}{*}{$\begin{array}{l}15^{\circ} \mathrm{C}, \quad \text { visible } \\
\text { light of } 70 \\
\mu \mathrm{Em}^{-2} \mathrm{~S}^{-1}\end{array}$} \\
\hline Chaetoceros. calcitrans & $10^{5}-10^{6}$ & $100-400$ & Yes & 9 & \\
\hline Phaeocystis globosa & -- & $\leq 730$ & Yes & 6 & \\
\hline \multirow{2}{*}{ Microcystis aeruginosa } & \multirow{2}{*}{$10^{6}$} & $50 \sim 100$ & Yes & $3-5$ & \multirow{7}{*}{$\begin{array}{l}\text { In the Light } \\
\text { incubator }\end{array}$} \\
\hline & & $200 \sim 350$ & No (10-day & servation) & \\
\hline Anabaena flosaquae & $10^{6}$ & $50 \sim 200$ & Yes & $1-3$ & \\
\hline Oscillatoria planctonica & $10^{6}$ & 200 & Yes & 2 & \\
\hline Chlorella vulgaris & $10^{6}$ & 200 & Yes & 3 & \\
\hline Scenedesmus obliquus & $10^{6}$ & $50-200$ & Yes & $2-7$ & \\
\hline \multirow[t]{2}{*}{ Synedra acus } & $10^{6}$ & $20-200$ & Yes & $2-9$ & \\
\hline & & 260 & Yes & 5 & \multirow{8}{*}{$\begin{array}{c}32.5 \mathrm{PSU}, 23.4^{\circ} \mathrm{C}, \\
\mathrm{PH}=8.15 \text {, dark }\end{array}$} \\
\hline \multirow[t]{2}{*}{ Organisms $\geq 50 \mu m$} & $>10^{5}$ & $260\left(+\mathrm{TiO}_{2}\right)$ & No & 5 & \\
\hline & \multirow{3}{*}{$>10^{3}$} & 260 & Yes & 5 & \\
\hline \multirow[t]{2}{*}{$10 \mu m \leq$ organisms $<50 \mu m$} & & $260\left(+\mathrm{TiO}_{2}\right)$ & No & 5 & \\
\hline & & 260 & Yes & 5 & \\
\hline \multirow[t]{2}{*}{ Heterotrophic bacteria } & \multirow[t]{2}{*}{$10^{4}$} & $260\left(+\mathrm{TiO}_{2}\right)$ & Yes(less) & 5 & \\
\hline & & 260 & Yes & 5 & \\
\hline E. coli & $10^{4}$ & $260\left(+\mathrm{TiO}_{2}\right)$ & Yes(less) & 5 & \\
\hline
\end{tabular}

Chlorella autotrophica, Chaetoceros calcitrans and Phaeocystis globosa have been observed to recover after UVC irradiation during 5-day to 9-day culture, when the cells are placed in a rich 
medium[6]. Chaetoceros calcitrans may form cysts (resting spores) as long as exposure at the lower UV doses, which may due to the physiological characteristics of diatom species to create a silica cells wall for protection against hostile environment. However, when they were exposed at higher doses, it seems no cysts will form and cells may recover on the 2nd day after UV treatment[6]. Phaeocystis globosa has been proved to be very sensitive to UVC radiation, which may lose photosynthetical activities at the higher UV irradiation[6].

Also, Microcystis aeruginosa, Anabaena flosaquae, Oscillatoria planctonica, Chlorella vulgaris, Scenedesmus obliquus recovered the growing after UVC treatment[7]. For shipboard tests, organisms $\geq 50 \mu \mathrm{m}$, and $10 \mu \mathrm{m} \leq$ organisms $<50 \mu \mathrm{m}$ also show the regrowth after UV alone treatment during 5-day retaining in the ballast tank[8]. Heterotrophic bacteria and E. Coli recover the productivity after UV alone treatment. However, if $260 \mathrm{~mJ} / \mathrm{cm}^{2} \mathrm{UVC}$ irradiation combines with $\mathrm{TiO}_{2}$, fewer amounts of organisms will be observed after 5-day retaining, and no obvious regrowth happens on organisms in two ranges of size.

Pathways of Organism Regrowth. Under UV irradiation, cell components of organisms are attacked, such as cell wall, protein, chloroplast, nucleus, chain of DNA, which may suffer damages in two steps. At first step, the cells of organisms may suffer dehydration to lose intracellular water, and change in shape and size. Such periphery damages may not be lethal to organisms, and organisms can recover from the injuries in cell wall, protein, chloroplast. At the second step, cell membrane, structure and chains of DNA may be broken, and then pyrimidine dimer produces to connect the broken chains of DNA via the cycloaddition reaction. Such DNA damages are possible to be repaired by DNA repair enzymes, which exist in bacteria, cyanobacteria, fungi, plants, vertebrates, and even in antarctic ice microalgae[8]. Normally enzymes can play the role of damage recovery through two pathways: light repair and dark repair. In light repair, the bonds between pyrimidine dimers are cut down when exposure at 400-700nm visible lights. While in dark repair, the pyrimidine dimers are removed or the damaged DNA are recombined, without the participation of visible lights. After light or dark repairs, organisms will probably recover the normal physiological function.

For ballast water treatment, nucleus and chains of DNA are supposed to be hurt under high UV irradiation doses. As long as the nuclear damage is so heavy that DNA repair enzymes cannot take repair effects properly, the organisms may die and cannot regrow. However, if the damage from UV treatment is not such heavy, pyrimidine dimers produced in DNA will be broken or removed via light recovery or dark recovery, with the aid of DNA repair enzyme.

\section{Inhibition of Organism regrowth after UV irradiation}

How to inhibit the organism regrowth in the UV-based systems will be a main task for ballast water treatment. In one way, if the UV radiation intensity is high enough to destroy cells of organisms completely, the repair effects cannot occur. For example, DNA of Tetraselmis sp has been detected to be decomposed under high UV dose, which may lead to the dead of Tetraselmis sp [9]. Also, irreversible damage can occur on bacteria when exposure at high UV doses [10]. In another way, the UV-photocatalytic treatment may inhibit the regrowth of organisms. Photocatalysts can produce active oxides (such as $\cdot \mathrm{OH}, \cdot \mathrm{O}_{2}{ }^{-}$and $\cdot \mathrm{OOH}$ ) under $\mathrm{UV}$ radiation, which enhances the oxidation ability in the system. The active oxides may hurt the permeability of cell wall and cell membrane, and then damage the metabolism and DNA of cells. Then the DNA repair enzymes may lose effects of repair. Therefore, UV- $\mathrm{TiO}_{2}$ may become an effective way to curb the light and dark reparation after UV irridiation. In fact, the UVC photocatalytic methods with nano $\mathrm{TiO}_{2}$ [11], $\mathrm{ZnO}$ [12] or $\mathrm{Ag}-\mathrm{TiO}_{2}$ have been reported to be able to extend the recovery time or minize the regrowth amounts $[13,14]$. UVC-photocatalytic may be able to completely inhibit the bacteria regrow since the size and structure of bacteria is comparatively simple $[9,15]$, however, for algae it is hard to be thoroughly inactivation by photocatalysis. Though $\mathrm{UV} / \mathrm{TiO}_{2}$ performs better than $\mathrm{UV}$ alone on ballast water treatment, it can hardly be applied widely since the photocatalytic effects may be affected greatly by salinity in seawater [16]. 


\section{Conclusions}

In summary, organism regrowth within treated ballast water has been observed in the UV-based systems after 1 to 9days. It is hard for UV-based systems to satisfy the regrowth evaluation of the new G8 guidelines. Hence, it is urgent to seek an effective way to enhance UV irradiation to inhibit the organism regrowth in the UV-based systems. Increasing UV doses or adding photocatalysts could be the available options for regrowth inhibition. However, bacteria may be totally decomposed in these ways but not all types of algae can be completely inactivated for the protections of cell walls or cyst forms. In addition, UV-photocatalytic method may be affected greatly by salinity in seawater. Therefore, it is still a long way to go to modify the UV-based treatment methods for the approval of the new G8 guidelines; otherwise the onboard installation of ballast water treatment systems may lose the significance.

\section{Acknowledgements}

Deeply appreciate the supports from the National Key Research and Development Project (2017YFC1404605), and College Students' Innovation and Entrepreneurship Training Project of Dalian Maritime University (School level,2017 \& Provincial level,2018).

\section{References}

[1] N.Nosrati-Ghods, M.Ghadiri, and W.G.Fruh: Mar. Pollut. Bull. Vol. 114(1) (2017), p. 428.

[2] M. Gregg, G. Rigby and G.M. Hallegraeff Aquatic Invasions Vol. 3(4) (2009), p. 44.

[3] M. David and S. Gollasch: Mar. Pollut. Bull. Vol. 56(12) (2008), p. 1966.

[4] Y. Shi, S. Jing, X.D. Jin, X. Li, L.C. Dai, and S.Y. Gao: J. INVEST. MED. Vol. 424(18) (2012), p.27.

[5] S. Riley, E. Lemieux, and S. Robbins: J. APPL. PHYCOL. (2005), Vol.24, p.751.

[6] Z. Lei: Master's Thesis, Hunan University, (2013).

[7] Y. Tao, X.Z. Mao, X.H. Zhang, K. Yuan, W.T. Doris: J Tsinghua Univ(Sci\& Tech) Vol. 50(9) (2010), p 1412.

[8] N. Zhang, K. Hu, and B. Shan: Chem. Eng.J. Vol. 243 (2014), p. 7.

[9] Z. Sun and E.R. Blatchley: Water Res. Vol. 121 (2017), p. 311.

[10] C. Shang, L.M. Cheung, C.M. Ho, and M. Zeng: Appl. Catal. Vol. 89(3-4) (2009), p. 536.

[11]D. Wu: Doctoral Thesis, Harbin Institute of Technology, (2011).

[12] P. Sathe, M.T.Z. Myint, S. Dobretsov, and J. Dutta: Sep. Purif. Technol. Vol. 162 (2016), p. 61.

[13] X. Liao: Doctoral Thesis, Huazhong University, (2009).

[14]Z.J. Ren, L. Zhang, Y. Shi, J. C. Shao, X. D. Leng, and Y. Zhao: J. Residuals Sci. Tech. Vol. 13(1) (2016), p. 31.

[15] Y.H. Chen and C. Lin: Shanghai Environ. Sci. Vol. 34(5) (2015), p. 5.

[16] J. Moreno-Andrés, L. Romero-Martínez, A. Acevedo-Merino and E. Nebot: Sci. Total. Environ. Vol. 581-582 (2017), p. 144. 